\title{
DROWNING, SHIPWRECK, SAILING: T. S. ELIOT'S VOYAGE OF TRANSFORMATION
}

\author{
Dídac Llorens-Cubedo, UNED ${ }^{1}$ \\ Email: dllorens@flog.uned.es
}

\begin{abstract}
Drowning, shipwreck and sailing are recurrent images in Eliot's poetry. Prufrock's empty existence reaches a crisis imagined as drowning. "Death by Water" was originally the narrative of a doomed voyage, inspired by Dante's and Tennyson's portrayal of Ulysses. The Waste Land contains allusions to the shipwreck in The Tempest and to Ophelia's drowning, leaving Phlebas' end open to opposite interpretations. After his conversion, Eliot's poetry has a clear sense of religious purpose: in "Marina", Ash Wednesday or "The Dry Salvages", sailing symbolises mystic purgation; shipwreck and drowning are apocalyptic passageways to eternity. This imaginative evolution exemplifies Jung's archetype of transformation.
\end{abstract}

Keywords: poetry, imagery, literary analysis, literary influences, Modernism.

Title in Spanish: Ahogamiento, naufragio y navegación: el viaje de transformación de T.S Eliot.

Resumen: El ahogamiento, el naufragio y la navegación son imágenes recurrentes en la poesía de Eliot. La vacuidad de Prufrock le lleva a un ahogamiento simbólico. Originalmente, "Death by Water" narraba una travesía fatídica inspirada en el Ulises de Dante y Tennyson. The Waste Land alude al naufragio de The Tempest o al ahogamiento de Ofelia, confiriendo ambigüedad a la muerte de Phlebas. Tras su conversión, la poesía de Eliot adquiere una orientación religiosa: en "Marina", Ash Wednesday o "The Dry Salvages" la navegación simboliza la purgación mística; el naufragio y el ahogamiento son ritos de paso apocalípticos. Esta evolución ilustra el arquetipo de transformación jungiano. Palabras clave: poesía, imágenes, análisis literario, influencias literarias, Modernismo.

In her study of landscape symbolism in the poetry of T. S. Eliot, Nancy Duvall Hargrove considered "the sea and river" as "one of the major clusters of landscapes", signifying "eternity, destruction, creation, mystery" (1978: 15). ${ }^{2}$ There is little need to add that Eliot's sea was not always calm: in his comparative study T. S. Eliot and Dante, Dominic Manganiello stated that "shipwrecks and drowned bodies [...] form a recurrent pattern which haunts Eliot's imagination”. Manganiello describes the thematic range conveyed through this imagery: "from childhood memories of thwarted sexual desire to the horror of the marriage bed, from a vision of spiritual emptiness to one of spiritual awakening" (1989: 38). Some of the poet's main concerns, as we will see, are conveyed through the

Date of reception: 30 June 2013

Date of Acceptance: 8 October 2013

2 The author identifies five clusters, the other four being the city, the country, the desert and the garden. 
imagery of sailing, shipwreck and drowning, to be presently explored. The examination of these imaginative complexes, archetypal in essence, will involve the study of themes and sources and will prove that Eliot's use of imagery creates cohesion and confers an evolving, almost narrative quality to his poetry as a whole.

\section{INCONSEQUENTIAL DEATHS BY WATER}

Five years before the publication of The Waste Land, Eliot had published "The Love Song of J. Alfred Prufrock". ${ }^{3}$ Prufrock is perhaps Eliot's most vividly portrayed character: an ageing man who laments the vacuity of his life, who wanders the streets "when the evening is spread out against the sky | like a patient etherised upon a table" and is unable to enter a room where "the women come and go | talking about Michelangelo" (Eliot 1974: 3, 4). In the "song", the ladies are perceived only as sound: their walking up and down the room, their chatter. Prufrock listens from the staircase and does not dare —or care - to face them; consequently, they remain unaware of his presence.

The theme of the poem has been formulated as "the speaker's [i.e. Prufrock's] uncertainty about the value of expressing the inner self, were that even possible". The end of the poem reveals that remaining in the "chambers of the sea" is fatal for Prufrock: his retiring nature becomes "a death sentence", since "what is home for the mermaids is not, after all, home for the human "I"" (Videnov 2009: 129-130). The "chambers of the sea" are the space of Prufrock's tragic retreat, from which he faintly hears the women and imagines the sea-girls that will not sing to him. Mermaids may be considered to represent "the torment of desire leading to self-destruction, for their abnormal bodies cannot satisfy the passions that are aroused by their enchanting music and by their beauty of face and bosom" (Cirlot 1971: 298). But Prufrock (like Gerontion, also considered below) is not Ulysses or any of his fellow seamen, facing the risk of letting themselves be charmed and led to death by the sea-girls' song. In an intriguing, almost parodic reversal, Prufrock drowns when woken up by dull human voices - those of the women in the room, a particularly demanding expression of social pressure:

We have lingered in the chambers of the sea

By sea-girls wreathed with seaweed red and brown

Till human voices wake us, and we drown (Eliot 1974: 7).

In Prufrock's particular case, self-repression is not totally indistinct from impending self-destruction. His "love song" is far from being an epic and the mesmeric singing of the sea-girls is just a sad fantasy set against the unseen ladies' talk, the "human voices" powerful enough to cause the man listening to drown symbolically. Prufrock's inability to express himself is a symptom of spiritual death that results in a symbolic death by water. He drowns, regretting things he never did and lamenting the barrenness of a life that could

\footnotetext{
3 The poem opened the Collection Prufrock and Other Observations. The Waste Land was first published in 1922.

4 Quotations of Eliot's poems are from Collected Poems 1909-1962, unless otherwise specified. As in the edition used, line numbers are only provided for The Waste Land.
} 
have been an adventurous sea journey. Painfully aware, Prufrock grotesquely imagines an alternative existence as a crustacean: "I should have been a pair of ragged claws $\mid$ Scuttling across the floors of silent seas" (Eliot 1974: 5).

Mr Apollinax, another of Eliot's creatures, meets the same fate as Prufrock ${ }^{5}$. The character after whom the poem is titled seems to have been inspired by Bertrand Russell, who had met Eliot and his first wife Vivien, shortly after they married. The philosopher helped the young couple financially, but he also flirted with the unstable Vivien. Years later, when Eliot considered separating from Vivien, he felt that Russell was partly responsible for the worsening of her nervous crises (Ackroyd 1984: 150). Contrasting with Prufrock's sexual timidity, Mr Apollinax is portrayed as a sardonic satyr: "Priapus in the shrubbery Gaping at the lady in the swing" (Eliot 1974: 23), a figure vaguely reminiscent of Neptune, hiding undersea in the company of drowned men:

His laughter was submarine and profound

Like the old man of the sea's

Hidden under the coral islands

Where worried bodies of drowned men drift down in the green silence,

Dropping from fingers of surf. (Eliot 1974: 23)

Eliot's interest in ancient ritual can already be detected in this poem. As part of the rituals of Adonis in Alexandria, Jessie Weston describes, in From Ritual to Romance, the custom of casting into the sea a reproduction of the god's head and the celebrations that followed its appearance on a distant shore, a few days later (1997: 43) ${ }^{6}$. But typically in Eliot's early poetry, ritual is not fulfilled and becomes tinged with the grotesque and parodic: Mr Apollinax's has "seaweed in its hair", but it is imagined by the lyrical speaker "rolling under a chair | or grinning over a screen" (Eliot 1974: 23). The poem ends in banal confusion - rather than the ecstatic celebration of rebirth-, in fragmented utterances, to a certain extent comparable to the polyglot collage of quotations appearing at the end of The Waste Land. In the latter poem, Stetson's fertitility rite is ineffective: the effigy of the Egyptian god Osiris, which he has planted in his garden, never sprouts ${ }^{7}$.

\section{THE LOST SHIPWRECK}

The drowned men in "Mr. Apollinax" "drift down in the green silence" (Eliot 1974: 23). They move delicately and placidly like Phlebas' bones, picked by the currents "in whispers" (Eliot 1974: 65). Phlebas' drowning is at the heart of The Waste Land. In the original drafts of the poem (first published in 1971), the section "Death by Water" was a narrative

\footnotetext{
5 The poem "Mr. Apollinax" was also included in Prufrock and Other Observations.

6 In his own notes to The Waste Land, Eliot acknowledges his indebtedness to Weston: "Not only the title, but the plan and a good deal of the incidental symbolism of the poem were suggested by Miss Jessie Weston's book on the Grail legend: From Ritual to Romance" (1974: 70).

7 See parts V and I of The Waste Land: "What the Thunder Said", 11. 424-434, and "The Burial of the Dead", 11. 69-76. As Frazer explains (1993: 376), the worshippers of Osiris moulded and buried moistened effigies of the god with seeds inside. Their sprouting was interpreted as a sign of the god's power and of future abundant crops.
} 
sequence telling of a sea journey with an idyllic beginning and a catastrophic conclusion. ${ }^{8}$ Towards the end of the adventure, the poetic speaker (presumably the boatswain) voices the collective despair, in the face of shipwreck that seems inevitable:

And when the lookout could no longer hear

Above the roar of waves upon the sea

The sharper note of breakers on a reef,

We knew we had passed the farthest northern islands

So no one spoke again. We ate slept drank

Hot coffee, and kept watch, and no one dared

To look into anothers [sic] face, or speak

In the horror of the illimitable scream

Of a whole world about us. (11. 61-65) ${ }^{9}$

It is in this critical phase of the adventure that the poetic speaker sees three singing white-haired women. In a note, in the facsimile edition of The Waste Land drafts, Valerie Eliot specifically links these women with the sea-girls in "The Love Song of J. A. Prufrock" (Eliot 1971: 129). The narrator of "Death by Water" is horror-struck by the sirens' song, which forecasts disaster. Mistakenly, he feels that he is having a nightmare that he has the power to put an end to:

A song that charmed my senses, while I was

Frightened beyond fear, horrified past horror, calm,

(Nothing was real) for, I thought, now, when

I like, I can wake up and end the dream. (11. 69-72)

Valerie Eliot drew attention to the "Homeric overtones" of the original "Death by Water" (1971: 128), as well as to two other influences that can be more easily traced. ${ }^{10}$ The first is Canto XXVI of Dante's Inferno (more specifically, lines 133-142). Here Ulysses does not return to Ithaka after the Trojan War; instead, he sails the Strait of Gibraltar with his devoted comrades, "to follow virtue and knowledge". The climactic conclusion of Eliot's narrative resembles that of Dante's in that the unexpected shipwreck has something of a rite of passage. This impression is communicated by the images seen at the very last moment: Ulysses sees "a mountain [...] of such a height as I had never seen before" ". In Eliot's original "Death by Water", sailors enter "a different darkness" as they approach "a long white line, | a wall, a barrier" and his protagonist states that "there is no more noise now" (11. 76-77, 83). Both narrators attribute the tragic end to the divine design of "Another".

\footnotetext{
8 The titles of the five parts of The Waste Land are: I. The Burial of the Dead, II. A Game of Chess, III. The Fire Sermon, IV. Death by Water and V. What the Thunder Said.

9 Quoted from The Waste Land. A Facsimile and Transcript of the Original Drafts Including the Annotations of Ezra Pound, ed. by Valerie Eliot. Since lines are numbered, the reference is to these instead of page numbers. 10 Although there are no explicit allusions, Coleridge's The Rime of the Ancient Mariner (1798) and Canto II ("The Shipwreck") of Byron's Don Juan (1819-24) may have also been at the back of Eliot's mind.

11 In the bilingual edition used, the Italian text is edited and translated into English by John D. Sinclair. For the English translation of the lines commented on, see p. 327 of Inferno.
} 
The other text alluded to is the poem Ulysses, by Alfred Tennyson, who, like Eliot, found inspiration in the story of the Greek hero as told by Dante. The lyrical speaker is a mature Ulysses who reflects on the intensity of what he has lived. In his imagination, the eventful journey of his life intersects with the realm of unlived possibility:

Yet all experience is an arch wherethro'

Gleams that untravell'd world, whose margin fades

For ever and for ever when I move. (11. 19-21) ${ }^{12}$

Tennyson's Ulysses envisages and cherishes what still might be, and this reflection spurs him to undertake his final odyssey:

The lights begin to twinkle from the rocks:

The long day wanes: the slow moon climbs: the deep

Moans round with many voices. ${ }^{13}$ Come, my friends,

'Tis not too late to seek a newer world.

Push off, and sitting well in order smite

The sounding furrows; for my purpose holds

To sail beyond the sunset, and the baths

Of all the western stars, until I die. (11. 54-61)

Conversely, and as we saw above, the unheroic Prufrock compares his actual life with an ideal that is no longer attainable. He continues in a state of inertia, and drowns. Manganiello has compared this anti-hero with another of Eliot's early characters, Gerontion: "Like Prufrock, he has seen his moments of greatness flicker. A stationary Ulysses, he has no song of the sirens to tempt his ears" (1989: 27). Although, according to Dante, Ulysses' doom is shipwreck and hell, he meets it after a noble quest for knowledge. By contrast, Gerontion will end his life as a puny and disoriented seagull:

Gull against the wind, in the windy straits

Of Belle Isle, or running on the Horn,

White feathers in the snow, the Gulf claims,

And an old man driven by the Trades

To a sleepy corner. (Eliot 1974: 31) ${ }^{14}$

Eliot's early characters inevitably pale when set aside Tennyson's ageing Ulysses and even the protagonist of the unedited "Death by Water". The vicissitudes of this section's composition are well known: Ezra Pound advised his protégé to suppress about ninety per

12 Cf. "What might have been is an abstraction | Remaining a perpetual possibility $\mid$ Only in a world of speculation." ("Burnt Norton", Four Quartets). As with other poetic sources with numbered lines, only line numbers are cited. Full details are given in the list of references.

13 As Valerie Eliot indicates (1971: 128), there may be an echo of this line in movement I of "The Dry Salvages" (Four Quartets): “The sea has many voices, | Many gods and many voices". Interestingly, the Dry Salvages (a rocky landmark near Cape Ann, in Massachusetts) are first mentioned, in Eliot's poetry, in the original "Death by Water". "The Dry Salvages" is discussed below.

14 The poem "Gerontion" is included in the collection 1920. 
cent of the section and Eliot doubted whether it would be better to excise it altogether. In a letter to Eliot, Pound insists that "Death by Water" should be preserved, albeit reduced in its length: "I DO advise keeping Phlebas. In fact I more'n advise. Phlebas is an integral part of the poem [...] and he is needed ABSolootly where he is. Must stay in" (Eliot 1988: 505) ${ }^{15}$.

Shipwreck imagery was largely suppressed from the original "Death by Water". The section is only ten lines long in its definitive version, being initially about ninety. Stephen Spender approved of Pound's editing task in general terms, but referred to the omitted evocation of Ulysses' seafaring as "the only long passage to be regretted" (1975: 95). The suppression has been justified invoking Eliot's mentor's poetic ideals: "to cut the preceding four pages of setting, description and characterization is the essence of modern poetry as Pound imagined it"; in retrospect, "the entire section reads as though it exists merely as a set-up for the chill-inducing beauty of the last ten lines" (MacKenzie 2011: 61). Eventually, drowning became the central image of "Death by Water". Only the corollary, markedly different in tone and mood from the preceding narration of shipwreck, remained:

Phlebas the Phoenician, a fortnight dead,

Forgot the cry of gulls, and the deep sea swell

And the profit and loss.

A current under sea

Picked his bones in whispers. As he rose and fell

He passed the stages of his age and youth

Entering the whirlpool.

Gentile or Jew

O you who turn the wheel and look to windward,

Consider Phlebas, who was once handsome and tall as you.

(11. 312-321)

These lines, with their memento mori theme, were recycled from a French poem by Eliot, "Dans le Restaurant", which combines a waiter's lewd description of a childhood sexual experience with a customer's thoughts, expressing annoyance and suggesting shock. The last stanza causes the poem's tone to change radically. We learn of Phlebas' pain and suffering, as he sees his life in retrospect, after death by water:

Phlébas, le Phénicien, pendant quinze jours noyé,

Oubliait les cris des mouettes et la houle de Cornouaille,

Et les profits et les pertes, et la cargaison d'étain:

Un courant de sous-mer l'emporta très loin,

Le repassant aux étapes de sa vie antérieure.

Figurez-vous donc, c'était un sort pénible;

Cependant, ce fut jadis un bel homme, de haute taille.

(Eliot $1974:$ : 43-44) ${ }^{16}$

\footnotetext{
15 Spelling peculiarities are those of the edition used, and presumably of the manuscript. Valerie Eliot also quotes these lines in one of her notes to the facsimile edition of The Waste Land (1971: 129).

16 "Dans le Restaurant" appeared, together with three other poems in French, in the collection 1920. Except for a couple of details (the sea swell at Cornouaille and the cargo of tin) the lines in The Waste Land quoted above are evidently a translation of these.
} 
Phlebas the Phoenician is one of the facets of a unique hermaphrodite character, as Eliot tells us in his note about Tiresias, whom he considers "the most important personage in the poem, uniting all the rest" (1974: 72). The reader has come across Phlebas in the preceding section of the poem ("The Fire Sermon") as Mr. Eugenides, the Smyrna merchant who carries currants in his pocket and propositions the lyrical speaker. In the "The Burial of the Dead", "Madame Sosostris, famous clairvoyante" (1. 43) had seen "the drowned Phoenician sailor" on one of her Tarot cards and exclaimed "those are pearls that were his eyes" (11. 47-48). This line is taken from one of Ariel's songs in William Shakespeare's The Tempest:

Full fathom five thy father lies,

Of his bones are coral made;

Those are pearls that were his eyes

Nothing of him that doth fade,

But doth suffer a sea-change

Into something rich, and strange

Sea-nymphs hourly ring his knell. (I.2.397-403) ${ }^{17}$

The sprite sings to Ferdinand, the Prince of Naples, who worries over his father's fate after the shipwreck. Eliot parodied these lines in "Dirge", one of "The Miscellaneous Poems" that he intended to append to The Waste Land. In it, a Jew named Bleistein undergoes a degrading and disturbing sea-change that caused Christopher Ricks to famously describe the poem as "the ugliest touch of anti-Semitism in Eliot's poetry" (1988: 38) ${ }^{18}$. Again, Pound urged his disciple to discard these peripheral poems, arguing they did not add significantly to the whole (Eliot 1971: 131).

Ariel's "those are pearls that were his eyes" and Ferdinand's lines when he notices the singing ("Weeping again the king my father's wreck, I This music crept by me upon the waters", I.2.391-392) are quoted or evoked through Eliot's poem, becoming as it were displaced refrains that, being set in unexpected contexts, produce an ironic and bittersweet effect: in "A Game of Chess", a dysfunctional dialogue between a man and a woman, where her nervous incoherent questions are juxtaposed to his remembering the mutation of the king's eyes into pearls; ${ }^{19}$ in "The Fire Sermon", the musings of a man fishing in a suburban setting. "The nymphs are departed" (11. 175 and 179) and Ariel's music does not creep upon the waters:

A rat crept softly through the vegetation

Dragging its slimy belly on the bank

While I was fishing in the dull canal

On a winter evening round behind the gashouse

17 For Shakespeare's The Tempest and Hamlet, act, scene and line numbers are cited.

18 Two versions of "Dirge" are included in The Waste Land. A Facsimile and Transcript (pp. 118-121). Bleistein is presented as a prototypical Jew in "Burbank with a Baedeker: Bleistein with a Cigar" (Poems), a poem set in decadent Venice.

19 In his note to verse line 138, Eliot refers readers to Thomas Middleton's play Women Beware Women. In a famous scene, the development of a chess game parallels the lovers' romantic advances. Further, and although Eliot does not mention this, at the end of The Tempest (act V) "Prospero discovers Ferdinand and Miranda, playing at chess". 
Musing upon the king my brother's wreck

And on the king my father's death before him. (11. 190-195) ${ }^{20}$

Eliot turns to The Tempest — and the same could be said of Frazer's The Golden Bough and Weston's From Ritual to Romance, his two main sources - because he is attracted to the notions of regeneration following decay and rebirth following death. That is why Phlebas' "Death by Water" is a turning point in The Waste Land. Does he "suffer a sea-change", after his life is carried away by the whirlpool?

\section{ABSOLUTE END OR NEW LIFE?}

Phlebas' drowning has been interpreted in opposite ways. The sailor's fate can be read as the irrevocable end of his existence: contrary to the common interpretive impulse, the images of water and drowning should preserve their immediate meanings. As Jewel Spears Brooker and Joseph Bentley convincingly argue for, "the 'death' in 'Death by Water' can mean the negation that precedes affirmation; or it can mean that old archetypes are themselves dead and thus suggest that water is only water for drinking or for drowning" (Brooker and Bentley 1990: 161).

It can be contended, therefore, that water is only water, its objectivity in the poem resulting from a strategy of anti-symbolist demythologising and suitable in the parallel world of the poem-a world where myth and ritual have become meaningless. Since the overall imaginative design of The Waste Land sets the scene for water to be perceived as a symbol of life, its literal presentation, therefore, breaks readers' expectations and constitutes one of the poem's strengths: "It is hard to imagine water in a context of dryness, lovelessness, anomie, and disorder failing to be a symbol of hope. Its defeat as a symbol, its status as antisymbol, is thus a special achievement" (Brooker and Bentley 1990: 165).

Coherently, drowning is only drowning: Phlebas' death is literal and not symbolic. The Phoenician Sailor is engulfed and his body - unlike King Alonso's- is washed out by the currents without a trace. He will not return from the "chambers of the sea" and his mortality results in strict, appalling nothingness: "Phlebas does not seem to be preparing for rebirth. On the contrary, he is described as quietly decomposing and entering the whirlpool. The water cleanses his bones, not symbolically but literally; the death by water is death by water" (Brooker and Bentley 1990: 162).

The interpretation of Phlebas' drowning as absolute end -in fact, its non-interpretation-is supported by the section's context. "What the Thunder Said", which follows "Death by Water" and closes the poem, evokes an inhospitable setting, arid and rocky, and would therefore confirm that rebirth is to nothing but the same despair that reigned before drowning. The lack of punctuation in the following lines accentuates the asphyxiating effect:

\footnotetext{
20 Martin Scofield (1999: 124-125) explains the disconcerting references to both a brother and a father by suggesting that Eliot causes Shakespeare's characters (Ferdinand, his father Alonso and the latter's brother, Sebastian; Prospero and his brother Antonio) to merge, in the same way as Tiresias sums up all characters, male and female.
} 
Here is no water but only rock

Rock and no water and the sandy road

The road winding above among the mountains

Which are mountains of rock without water

If there were water we should stop and drink

Amongst the rock one cannot stop or think

Sweat is dry and feet are in the sand

If there were only water amongst the rock

Dead mountain mouth of carious teeth that cannot spit

Here one can neither stand nor lie nor sit

There is not even silence in the mountains

But dry sterile thunder without rain (11. 331-342) ${ }^{21}$

As we read the opening stanzas of "What the Thunder Said", we have the feeling that the demonic desert has prevailed ${ }^{22}$. There are equally valid grounds, however, for seeing Phlebas' death as the precedent of resurrection. Eliot's appropriation of myth and religious symbolism is ambivalent: it demythologises through adulteration but paradoxically, at the same time, it re-mythologises through adaptation to contemporary life-the essence, arguably, of the Modernist mythical method. In the context of a poem dominated by images of dryness, the readers' expectation is that water will restore fertility-and particularly in "Death by Water", the dead sailor's life. This interpretation can be supported by the knowledge that in Eliot's sources, death gives way to a new form of existence (Brooker and Bentley 1990: 160). Therefore, Phlebas' drowning can also be regarded as a cleansing baptism through which the Phoenician sailor crosses into a new sphere of being and is born to a new life (Patea 2005: 148).

Water and fire compare as purifying symbols. Before The Waste Land concludes with a peace bringing benediction in Sanskrit ("shantih shantih shantih", 1. 434), we find a hint at purgation through fire: the line "Poi s'ascose nel foco che li affina" ("then he hides in the fire that refines them"), taken from Dante's Purgatorio (XXVI.148) ${ }^{23}$. Also in the last stanza, the line "These fragments I have shored against my ruins" (1. 431), which summarises the poem like no other, would seem to indicate that there is still room for hope. The text allows readers to assume that the line is spoken by Shakespeare's Ferdinand whose father, King Alonso, is persuaded that his son has met death by water:

Even here I will put off my hope, and keep it

No longer for my flatterer: he is drown'd

Whom thus we stray to find, and the sea mocks

Our frustrate search on land. (III.3.7-10)

\footnotetext{
21 Eliot's own reading of these lines, in which the desired effect is noticeable, is worth listening to (the audio book T. S. Eliot Reading "The Waste Land", "Four Quartets" is included in the list of references).

22 The term demonic is used by Northrop Frye (1982: 139-140) to refer to Biblical images (and their literary echoes) conveying vain ostentation or environmental degradation associated, in the Old Testament, with heathen nations.

23 The translation of the line, which can be found on p. 349 of Purgatorio, is by John D. Sinclair. The image of purgative fire is more meaningfully used in "Little Gidding", the last of Four Quartets.
} 
But father and son are reunited in the final act, in which Ferdinand is symbolically reborn in a dream-like atmosphere. The prince is dead only in the king's thoughts, but an actual death by drowning is brought to mind by the closing lines of "A Game of Chess". Juxtaposed to the bitter realism of the famous pub scene (11. 139-171), the reader finds mad Ophelia's last words in Hamlet, as she takes her leave of Claudius, Gertrude and Horatio: "Good night, ladies, good night, sweet ladies, good night, good night" (IV.5.69-70; 1. 172 of The Waste Land). Two scenes later, Queen Gertrude relates how Ophelia, arrayed with "fantastic garlands", "fell in the weeping brook", for a moment floated "mermaid-like" and finally succumbed "to muddy death" (IV.7.165-182). At Ophelia's burial, her brother Laertes is confident that her sister's soul will be granted eternal life after a rebirth expressed through natural imagery:

Lay her i'the earth

And from her fair and unpolluted flesh

May violets spring! (V.1.223-225)

Ophelia has been identified with the hyacinth girl in "The Burial of the Dead" (11. 3541): innocent, fragile, heartbroken. In The Waste Land, this impression of unfulfilled love is framed by two quotations of the libretto of Richard Wagner's Tristan und Isolde (1865). The first one is from a sweet melody sung by a young sailor: it predicts a safe sea voyage and functions as an ironic introduction to the hyacinth garden scene ${ }^{24}$. The second is more evocative of the lovers' feelings in Eliot's poem: the line "Oed'und leer, das Meer" (1. 42, "Waste and empty is the sea"), sung by a shepherd who is watching for the arrival of the ship that will bring Isolde to the dying Tristan, in the final act of the opera.

There is no hope for the hyacinth girl, nor for Ophelia. As Elizabeth Drew argues, the latter's death "is self-destruction, the end of frustrated love, not a baptism and regeneration into a new birth" (1970: 62). These notions lead back to the uncertainty surrounding the death of the Phoenician Sailor-as Eliot himself acknowledged, "not wholly distinct" from the Prince of Naples (1974: 72). Will Phlebas be-like Ferdinand, unlike Ophelia or the hyacinth girl-alive again? In other words, is regeneration achieved by an invocation of peace, through purgative fire or building from gathered fragments? The question is central to The Waste Land and there is no conclusive answer, but transcending the poem will shed some light.

\section{SAILING NEW SEAS}

Ariel Poems and Ash Wednesday were composed after Eliot's conversion to AngloCatholicism in 1927 and they mark a turning point in his work, coinciding with the emergence of a strong religious conscience. The young poet's work reflected his comprehensive Harvard education (philosophy, comparative literature, languages, history, art, political science), his veneration for Dante, and for the French Symbolistes-innovative masters of

24 "Frisch weht der Wind | Der Heimat zu | Mein Irisch Kind | Wo weilest du?" (11. 31-34, "Fresh blows the wind to the homeland; my Irish child, where are you waiting?"). Isolde is angered by the song, which she interprets as mockery directed against her. Translations of theses lines and of 1.42 have been taken from The Norton Anthology of English Literature, vol. I (p. 2296, 1n and 3n; see References). 
mood and symbolism ${ }^{25}$. It also explored forms of poetic expression, such as the satiric or grotesque veins of 1920, which will have no continuity (Mays 1996: 111), due to Eliot's new biographical circumstances. Likewise, he abandoned what Manganiello has called "the poetry of disillusionment"-of which The Waste Land or The Hollow Men would be the epitome and climax-to cultivate "the poetry of hope" (1989: 82). As a requisite, he had to "go outside the shipwrecked, solitary, solipsistic lyric self" that characterised some of his earlier verse (Mays 1996: 111; emphasis added).

Eliot's determination to strengthen his faith is reflected in the tone of Ash Wednesday, purgative and ascetic, and in its diction, in phrases like "redeem the time" or "the higher dream" (1974: 90, 91), which indicate a yearning for eternal life. Tone and purpose have evidently changed, but the imagery of the sea and sailing is still there: "the lost sea voices"26, "the lost sea smell", "the cry of quail and the whirling plover", "the salt savour of the sandy earth" (Eliot 1974: 94)-all attract "the lost heart", which seems to recall and intuit them at the same time. The call of the sea is the impulse to purge the spirit, and this process is imaged as a sea adventure that the lyrical speaker, carried away, cannot put off:

From the wide window towards the granite shore

The white sails still fly seaward, seaward flying

Unbroken wings (Eliot 1974: 94)

These lines, from section VI of Ash Wednesday, overcome the reluctance expressed in its opening (I): "Why should the agèd eagle spread its wings?" (Eliot 1974: 85). Having in mind Dante's portrayal of Ulysses and how inspiring it was for Eliot, Manganiello explains that, in Eliot's post-conversion poetry, old age is no longer spent in a state of paralysing frustration or remorse-as we saw, this was the case with Prufrock and Gerontion. Instead, it is metaphorically expressed as a transcendent journey: "the time for a new beginning rather than the end, a time for a sea-change of the soul when the old man dies and the new man is born" (1989: 33).

The poem "Marina" is especially relevant in tracing Eliot's poetic journey. It has been defined as "the poem of resolution", composed "at a vital stage in the record of his [Eliot's] spiritual development" (Dickens 1989: 154, 155; author's emphasis). The old man whose voice we hear, and who can be identified with Shakespeare's Pericles, describes his life stance as "living to live in a world of time beyond me" (Eliot 1974: 106) ${ }^{27}$. Determination, rather than surrender, will lead him to his destiny: "Here Pericles, like another Phoenician sailor Phlebas, passes the stages of his life and youth, rising and falling, entering not Phlebas' 'whirlpool' but a deeper acknowledgement of his responsibility" (Donogue 1996: 379). The poetic speaker compares himself to a ship that has suffered the hardships of the sea ("bowsprit cracked with ice and paint cracked with heat", "the rigging weak and the canvas rotten", "the garboard strake leaks, the seams need caulking"), but he is ready for "the hope, the new ships" (Eliot 1974: 106).

\footnotetext{
25 For a list of the courses that Eliot took at Harvard, see Jain 2004: 252-256.

26 See note 13 above.

27 The poem "Marina" (1930) is included in Ariel Poems. Marina is Pericles' daughter in Shakespeare's play.
} 
The old man in "Marina" gladly surrenders to the forces of the sea. In movement I of "The Dry Salvages", the third in the sequence of Four Quartets, the sea is imagined as the space that subsumes time. It contains a variety of objects, carried by the currents or sunk to its depths after shipwrecks, at different moments in time. These objects, together with sea fauna and flora, are returned to the temporal when the waves wash the shore, and may be examined as traces of mortal lives, ended and perhaps forgotten:

The sea is the land's edge also, the granite

Into which it reaches, the beaches where it tosses

Its hints of earlier and other creation:

The starfish, the horseshoe crab, the whale's backbone;

The pools where it offers to our curiosity

The more delicate algae and the sea anemone.

It tosses up our losses, the torn seine,

The shattered lobsterpot, the broken oar

And the gear of foreign dead men. (Eliot 1974: 192-193)

The all-containing sea is presented as an inescapable fate, desired and feared: "the menace and caress of wave that breaks on water" (Eliot 1974: 193). The wives of sailors and fishermen are painfully aware of this danger: also in movement I-in what could be considered an example of the practice of the mythical method-Eliot associates them with Penelope weaving, unweaving and waiting for Ulysses' return. As a boy, Eliot had spent his summer holidays in Gloucester, near Cape Ann; he was familiar with the sights and sounds of fishing communities, and he incorporated them to movement II of "The Dry Salvages": "bailing", "setting and hauling", "drawing their money", "drying sales at dockage" (Eliot 1974: 194) $)^{28}$. However, what the poet has in mind is not an ordinary routine, but "a trip that will be unpayable | for a haul that will not bear examination". The challenge and aspiration is to face the sea

In a drifting boat with a slow leakage,

The silent listening to the undeniable

Clamour of the last annunciation. (Eliot 1974: 194)

The boat will probably founder, the adventurer may drown, but this is now peacefully accepted as inevitable. Eliot's imagery of the soul's transition is coherent with Christian mysticism, but not exclusively: according to McNelly Kearns, "The Dry Salvages" evidences Eliot's familiarity with Indic philosophy and religion, "not as a source of easy consolation but as a challenge and warning to those who seek to cross the ocean of samsara [the ongoing cycle of birth and rebirth] in the small boats of safe doctrine or simple good works" (1987: 247)-partial devotion will not suffice.

Movement IV of "The Dry Salvages" is a prayer to the Virgin Mary, the protector of those whose livelihood depends on the sea. In it, Eliot has a thought for the "women who have

\footnotetext{
Eliot dedicated the last of the five poems of his sequence "Landscapes" (Minor Poems) to Cape Ann. The
} poem lists a number of local birds and evokes their singing, but contains no sea imagery. 
seen their sons or husbands | setting forth, and not returning", for all the lost lives. Unlike Phlebas, the drowned in "The Dry Salvages" have the prayer and intercession of the Lady:
Also pray for those who were in ships, and
Ended their voyage on the sand, in the sea's lips
Or in the dark throat which will not reject them
Or wherever cannot reach them the sound of the sea bell's
Perpetual angelus. (Eliot 1974: 198)

Shipwreck and drowning have been divested of their tragic connotations. On the other hand, the sea, because of its vastness without boundaries, has become an image of the timeless: it "encircles the land (our safe habitat) on all sides, the way eternity encircles time" (Howard 2006: 98). Hence, sailing could be regarded as a metaphor of the mystic journey, of the possibility to apprehend the timeless. In Four Quartets, Eliot finally uses this imagery confidently, in accordance with the solidity of his beliefs.

\section{A VOYAGE OF TRANSFORMATION (CONCLUSION)}

T. S. Eliot's poetic production is known not only for its highly allusive nature, but also for its cohesion, a quality achieved through the use of images that recur and evolve, constituting an objective correlative-in the poet's own terminology-that is a narrative of spiritual affirmation ${ }^{29}$. It may seem paradoxical when referring to a poet who gave such priority to poetic impersonality but, according to Drew, the poet's imagery and his inner life evolve in parallel, this imaginative evolution being a manifestation of the archetype of transformation: "the sequence in which the archetypal images arise in the course of his poetry, their interrelationships, and their final resolution into the design of Four Quartets, reflects in a strange way the succession in the appearance of the symbols which Jung has described as the archetype of transformation" (Drew 1992: 19; author's emphasis).

As we have seen, the images chosen for analysis run through Eliot's poetry, from Prufrock to the Quartets: drowning as the result of paralysis and solipsism, as unresolved ritual and finally, untimely end that responds to the divine order of things; shipwreck as the consequence of vain ambition or as the critical crossing of the frontier between mortality and eternity; sailing as determined spiritual progress, the courage to accept and surrender. It is beyond doubt that the poet reached a port.

\section{REFERENCES}

ACKroyd, P. 1984. T. S. Eliot. A Life. New York: Simon \& Schuster.

Cirlot, J. E. 1971. A Dictionary of Symbols. Mineola, N. Y.: Dover Publications.

DANTE. 1961. The Divine Comedy. 1: Inferno. New York: Oxford University Press.

---. 1961. The Divine Comedy. 2: Purgatorio. New York: Oxford University Press.

29 Eliot famously used this term in his essay "Hamlet and His Problems", completed in 1919. 
Dickens, D. 1989. Negative Spring. Crisis Imagery in the Works of Brentano, Lenau, Rilke and T. S. Eliot. New York: Peter Lang.

Donogue, D. 1996. “Eliot's 'Marina' and Closure”. The Hudson Review 49, 3: 367-388.

Drew, E. 1992. “T. S. Eliot: Mythical Vision”. Jungian Literary Criticism. Ed. Richard P. Sugg. Evanston, IL: Northwestern University Press. 9-20.

---. 1970. T. S. Eliot: the Design of his Poetry. Ballimaran: Lucky Press.

Duvall Hargrove, N. 1978. Landscape as Symbol in the Poetry of T. S. Eliot. Jackson: University Press of Mississippi.

ELIOT, T. S. 1974. Collected Poems 1909-1962. London: Faber \& Faber.

---. 2007. T. S. Eliot Reading “The Waste Land”, “Four Quartets” and Other Poems. New York: Harper Collins.

Eliot, V., ed. 1988. The Letters of T. S. Eliot. San Diego: Harcourt Brace Jovanovich.

--- ed. 1971. The Waste Land. A Facsimile and Transcript of the Original Drafts Including the Annotations of Ezra Pound. Orlando, FL: Harcourt Books.

Frazer, J. G. 1993. The Golden Bough. A Study in Magic and Religion. Ware, Hertfordshire: Wordsworth.

FrYe, N. 1982. The Great Code. The Bible and Literature. San Diego: Hartcourt Brace.

Howard, T. 2006. Dove Descending. A Journey into T. S. Eliot's "Four Quartets". San Francisco: Ignatius Press.

JAIN, M. 1992. T. S. Eliot and American Philosophy. The Harvard Years. Cambridge: Cambridge University Press.

MacKenzIE, C. 2011. “The Poem as Situation: Eliot's Meaning and Pound's Truth in The Waste Land". The Waste Land at 90. A Retrospective. Ed. Joe Moffett. Amsterdam / New York: Rodopi. 51-72.

Manganiello, D. 1989 T. S. Eliot and Dante. Houndmills / London: MacMillan.

MaYs, J. C. C. 1996. "Early Poems: from 'Prufrock' to 'Gerontion'”. The Cambridge Companion to T. S. Eliot. Ed. A. D. Moody. Cambridge: Cambridge University Press. 108-120.

McNelly Kearns, C. 1987. T. S. Eliot and Indic Traditions: A Study in Poetry and Belief. Cambridge: Cambridge University Press.

PateA, V. 2005. “Introducción”. La tierra baldía. Ed. V. Patea. Madrid: Cátedra. 8-189.

Ricks, C. 1988. T. S. Eliot and Prejudice. Berkeley and Los Angeles: University of California Press.

ShaKespeare, W. 2003. Hamlet. Ed. Burton Raffel. New Haven and London: Yale University Press.

---. 1999. The Tempest. London: Arden Shakespeare. 
Scofield, M. 1999. "Poetry's Sea-Changes: T. S. Eliot and The Tempest". Shakespeare Survey 43. The Tempest and After. Cambridge: Cambridge University Press. 121-129.

Spears Brooker, J. and J. Bentley. 1990. Reading “The Waste Land”. Modernism and the Limits of Interpretation. Amherst: University of Massachusetts.

SPENDER, S. 1975. T. S. Eliot. Harmondsworth: Penguin.

Tennyson, A. 2006. "Ulysses". The Norton Anthology of English Literature, II. Ed. Stephen Greenblatt. New York: Norton. 1123-1125.

Videnov, V. A. 2009. "Human Voices in Silent Seas: A Reading of Eliot's Love Song”. The Explicator 67, 2: 126-130.

Weston, J. 1993. From Ritual to Romance. An Account of the Holy Grail from Ancient Ritual to Christian. Princeton, NJ: Princeton University Press. 